\title{
Retraction
}

\section{Retracted: A Design of Double Broadband MIMO Antenna}

\section{International Journal of Antennas and Propagation}

Received 10 March 2016; Accepted 10 March 2016

Copyright (C) 2016 International Journal of Antennas and Propagation. This is an open access article distributed under the Creative Commons Attribution License, which permits unrestricted use, distribution, and reproduction in any medium, provided the original work is properly cited.

The article titled "A Design of Double Broadband MIMO Antenna" [1] has been retracted at the request of the authors. The paper was found to include incorrect figures and data, affecting the validity of the conclusions.

\section{References}

[1] Y. Geng, R. Ma, B. Chen, and W. Zhang, "A design of double broadband MIMO antenna," International Journal of Antennas and Propagation, vol. 2015, Article ID 952137, 6 pages, 2015. 